\title{
Berberine exhibits antioxidative effects and reduces apoptosis of the vaginal epithelium in bacterial vaginosis
}

\author{
XIUZHEN MA*, JUNFENG DENG*, XINMU CUI, QI CHEN and WEIHUA WANG \\ Department of Obstetrics and Gynecology, Yantai Hospital of Traditional Chinese Medicine, \\ Yantai, Shandong 264000, P.R. China
}

Received September 29, 2018; Accepted May 31, 2019

DOI: $10.3892 /$ etm.2019.7772

\begin{abstract}
Bacterial vaginosis (BV) is a common type of vaginitis. Berberine is a natural alkaline product that reduces oxidative stress and apoptosis in cells. The aim of the present study was to investigate the effects of berberine on oxidative stress and apoptotic rates of BV. Vaginal epithelial and discharge samples were obtained from 60 healthy individuals and 180 patients with BV before and after one month of berberine treatment. Clinical observation was documented for all patients before and after treatment for comparison. Additionally, an in vitro study was performed; the samples were divided into groups the following groups: Control, model $\left(\mathrm{H}_{2} \mathrm{O}_{2}\right.$-treated), LT (low-dose berberine), MT (medium-dose berberine) and HT (high-dose berberine). Expression levels of the oxidative stress related proteins were detected by western blotting. Clinical symptoms of patients with BV significantly improved following berberine treatment. Oxidative stress in vaginal discharge was significantly lower following treatment, indicated by the increased activity of superoxide dismutase (SOD) and catalase, as well as the reduced levels of malondialdehyde and $\mathrm{H}_{2} \mathrm{O}_{2}$. Apoptosis of the vaginal epithelial cells was also reduced, which was indicated by the reduced expression of apoptosis proteins caspase-3, cytochrome $\mathrm{C}$, capase- 12 and $\mathrm{Bax}$, and increased expression of Bcl-2. The results of the in vitro experiments demonstrated a dose-dependent decrease in apoptosis with berberine treatment compared with levels before treatment. Oxidative stress relief was demonstrated by the reduced reactive oxygen species level and increased SOD and endothelial nitric oxide synthase levels, whereas suppression of apoptosis was further supported by the reduction in apoptotic proteins, as well as a decreased $\mathrm{Bax} / \mathrm{Bcl}-2$ ratio.
\end{abstract}

Correspondence to: Dr Weihua Wang, Department of Obstetrics and Gynecology, Yantai Hospital of Traditional Chinese Medicine, 39 Xingfu Road, Yantai, Shandong 264000, P.R. China

E-mail: qsqfcw8@163.com

*Contributed equally

Key words: berberine, bacterial vaginosis, oxidative stress, apoptosis, hydrogen peroxide
Berberine exhibited effects on lowering oxidative stress in vaginal discharge and reducing oxidative damage, as well as apoptosis of the vaginal epithelium, which are beneficial to patients with bacterial vaginosis.

\section{Introduction}

Vaginitis is an inflammation of the vagina, most cases of which are due to bacterial or fungal infections. Common types of vaginitis are bacterial vaginosis (BV), candida vaginitis and trichomoniasis; BV is the most frequent type (1-3). BV is caused by imbalances of the bacterial composition in the vaginal flora and excessive growth of bacteria on the vaginal epithelium, which results in inflammation (2). BV is often diagnosed with a vaginal $\mathrm{pH}$ of $>4.5$, or a Nugent score of $\geq 7$ (2). Common symptoms of BV include vaginal itching and pain, foul odor and excessive vaginal discharge (4). Although $\mathrm{BV}$ is not life-threatening, it creates significant discomfort and may lead to complications (2). Patients diagnosed with BV should be treated immediately.

The current standard treatment for $\mathrm{BV}$ is the administration of antibiotics, either locally or systematically (5). The commonly used antibiotics for BV treatment include metronidazole, clindamycin and tinidazole, which have been demonstrated to be effective with cure rates ranging between 75 and 86\% (6-8). Oral and vaginal treatments are available and demonstrate similar efficacy $(9,10)$. However, certain side effects have been noted, such as nausea and stomach discomfort (9). In addition, antibiotic treatments are associated with the development of antibiotic resistance; high antibiotic resistance (68-81\%) was observed in patients following metronidazole or clindamycin treatment, which lead to recurrence of BV (11-13).

Berberine is a natural alkaline product that has a long history of use in traditional Chinese medicine (14). It had been reported to exhibit beneficial effects for various diseases such as diabetes mellitus, kidney damage and cardiovascular disease (15-18). The underlying mechanisms of the effects of berberine are attributed to its ability to reduce oxidative stress and apoptosis in cells, which makes it a promising candidate for treating inflammation-related diseases or symptoms $(15,17)$. The aim of this study was to evaluate the effects of Berberine on BV as a potential alternative approach, especially for patients who have already developed resistance to antibiotic treatments. 
Evaluation of the effects of berberine on reducing oxidative stress and apoptosis in cells can be achieved by analyzing the changes in oxidative stress- and apoptosis-related factors in cells. Superoxide dismutase (SOD) is an enzyme in cells that catalyzes the conversion of superoxide anion radical $\left(\mathrm{O}_{2}{ }^{-}\right)$to the less harmful hydrogen peroxide $\left(\mathrm{H}_{2} \mathrm{O}_{2}\right)$, whereas catalase (CAT) is an enzymatic antioxidant that converts $\mathrm{H}_{2} \mathrm{O}_{2}$ into water and molecular oxygen $(19,20)$. Together, SOD and CAT serve important roles in reducing oxidative stress levels by reducing the amount of reactive oxygen species (ROS) in cells. Endothelial nitric oxide synthase (eNOS) is an enzyme that uses L-arginine to produce nitric oxide (NO) (21-24). NO can also reduce oxidative stress by scavenging ROS and activating antioxidative enzymes, such as SOD and CAT (25). In addition, malondialdehyde (MDA) is widely used as a marker for lipid peroxidation in cells (26-28). MDA is formed when ROS within cells oxidize unsaturated fatty acids; thus, it can also be used as an indicator for oxidative stress (28). Apoptosis is mostly mediated by Bax and the caspase family, whereas cytochrome $\mathrm{C}$ is released by the mitochondria to activate caspase during apoptosis $(29,30)$. Caspase-3, caspase-12 and the $\mathrm{Bax} / \mathrm{Bcl} 2$ ratio are commonly used as measures for apoptosis levels (31-33).

In this study, the changes in SOD, CAT, MDA and $\mathrm{H}_{2} \mathrm{O}_{2}$ were monitored in vaginal discharge from patients following berberine treatment to evaluate the changes in oxidative stress levels. Changes in the aforementioned apoptotic proteins in vaginal epithelial cells following berberine treatment were also monitored to evaluate the change in apoptosis levels. Furthermore, in vitro experiments were performed to evaluate changes in apoptosis and ROS levels in vaginal epithelial cells with different doses of berberine treatment.

\section{Materials and methods}

Patient grouping and treatments. A total of 180 female patients (age, 25-45 years) diagnosed with BV at Yantai Hospital of Traditional Chinese Medicine between August 2017 and March 2018 were selected for this study. The experiment exclusion criteria were as follows: i) Patients at menstrual bleeding; ii) pregnant patients; iii) lactating patients; iv) patients who were treated with antibiotics, hormones or local drug treatments within 14 days; v) patients who participated in sexual activity within $24 \mathrm{~h}$. Additionally, healthy individuals undergoing routine vaginal examination and 60 healthy female individuals (age, 25-45 years) were selected between August 2017 and March 2018 as the control group. Individuals were excluded from the current study if they were: i) Menstruating; ii) pregnant; iii) lactating; iv) treated with antibiotics, hormones or local drug treatments within 14 days; v) participated in sexual activity within $24 \mathrm{~h}$. Each BV patient was administered berberine treatments by placing $0.3 \mathrm{~g}$ berberine $\mathrm{HCl}$ (Northeast Pharmaceutical Group Co., Ltd.) at the posterior vaginal fornix daily for 10 days per treatment for one month. Clinical observation was performed on all healthy subjects (control) and on patients before treatment (BT) and after treatment (AT) to monitor and compare the severity of symptoms. Healthy subjects were only evaluated once. This study was approved by the Ethics Committee of Yantai Hospital of Traditional
Chinese Medicine. Written informed consent was obtained from all participants.

Sampling of vaginal discharge and vaginal epithelial cells. Observe the leucorrhea of the patient. Swabs of vaginal discharge and virginal epithelial cells were collected at the posterior vaginal fornix and the cervix from patients with BV and healthy subjects while the cervix was exposed using a vaginal speculum. Each swab was dissolved in $1 \mathrm{ml}$ phosphate-buffered saline (PBS; $0.05 \mathrm{~mol} / \mathrm{l} ; \mathrm{pH} 7.0$ ) in centrifuge tubes. Samples were centrifuged at $11,180 \mathrm{x} g$ under refrigeration at $4^{\circ} \mathrm{C}$ for $20 \mathrm{~min}$ and stored at $-80^{\circ} \mathrm{C}$ until further use.

Cell culture and treatment. Human vaginal epithelial cells VK2/E6E7 (cat. no. BNCC340628) were purchased from Shanghai Cell Library (http://www.cobioer.com/index.html). Cells were incubated in DMEM medium (Gibco; Thermo Fisher Scientific, Inc.) with $10 \%$ fetal bovine serum (FBS; Sigma-Aldrich; Merck $\mathrm{KGaA}$ ), at $37^{\circ} \mathrm{C}$ with $5 \% \mathrm{CO}_{2}$. Cells were treated with $0,10,50$ and $100 \mu \mathrm{g} / \mathrm{ml}$ berberine for $24 \mathrm{~h}$ prior to the MTT assay.

Induction of oxidative stress. VK2/E6E7 cells were divided into five groups: i) Control, samples incubated without FBS in the medium; ii) model, samples incubated without FBS in DMEM medium for $4 \mathrm{~h}$, followed by the addition of $400 \mu \mathrm{M}$ $\mathrm{H}_{2} \mathrm{O}_{2}$ for $24 \mathrm{~h}$; iii) LT, samples incubated in DMEM medium with $10 \mu \mathrm{g} / \mathrm{ml}$ berberine $\mathrm{HCl}$ for $4 \mathrm{~h}$, followed by the addition of $400 \mu \mathrm{M} \mathrm{H}_{2} \mathrm{O}_{2}$ for $24 \mathrm{~h}$; iv) MT, samples incubated in EMDM medium with $50 \mu \mathrm{g} / \mathrm{ml}$ berberine $\mathrm{HCl}$ for $4 \mathrm{~h}$, followed by the addition of $400 \mu \mathrm{M} \mathrm{H}_{2} \mathrm{O}_{2}$ for $24 \mathrm{~h}$; and v) HT, samples incubated in DMEM medium with $100 \mu \mathrm{g} / \mathrm{ml}$ berberine $\mathrm{HCl}$ for $4 \mathrm{~h}$, followed by the addition of $400 \mu \mathrm{M} \mathrm{H}_{2} \mathrm{O}_{2}$ for $24 \mathrm{~h}$. Each group consisted of five replicates.

ROS-related factor detection. Spectrophotometry was used for the detection of SOD (cat. no. BC0170) and CAT (cat. no. BC0200) activity, as well as levels of MDA (cat. no. BC0020) and $\mathrm{H}_{2} \mathrm{O}_{2}$ (cat. no. $\mathrm{BC} 3590$ ), within the vaginal discharge samples. SOD (cat. no. BC0170), CAT (cat. no. BC0200), MDA (cat. no. BC0020) and $\mathrm{H}_{2} \mathrm{O}_{2}$ (cat. no. BC3590) kits were purchased from Beijing Solarbio Science \& Technology Co., Ltd. and used following the manufacturers' protocols.

MTT cell viability assay. VK2/E6E7 cells in the logarithmic growth phase were digested using pancreatic enzymes, and cell density was adjusted to $1 \times 10^{5}$ cells $/ \mathrm{ml}$. The cells were transferred to a 96-well plate $(100 \mu \mathrm{l} /$ well $)$ and incubated at $37^{\circ} \mathrm{C}$ with $5 \% \mathrm{CO}_{2}$ in an incubator until $\sim 80 \%$ confluence was reached. The cells were grouped and treated as described above. At $24 \mathrm{~h}$, supernatants were removed, $20 \mu \mathrm{l}$ of $5 \mathrm{mg} / \mathrm{ml}$ MTT was added to each well and incubated for $4 \mathrm{~h}$ at $37^{\circ} \mathrm{C}$. Subsequently, supernatants were removed again and $200 \mu \mathrm{l}$ DMSO (Sigma-Aldrich; Merck KGaA) was added to each well and suspended evenly. Absorbance at $490 \mathrm{~nm}$ was detected using a photometric plate reader.

Flow cytometry. VK2/E6E7 cells in the logarithmic phase were digested using pancreatic enzymes, and cell density was adjusted to $1 \times 10^{5}$ cells $/ \mathrm{ml}$. The cells were transferred to 
a six-well plate $(1 \mathrm{ml} /$ well $)$ and incubated at $37^{\circ} \mathrm{C}$ with $5 \%$ $\mathrm{CO}_{2}$ in an incubator until the cells covered the bottom of the wells. The cells were grouped and treated as described above. Annexin V-FITC/propidium iodide (PI) Apoptosis Detection kit and Reactive Oxygen Species Assay kit (cat. nos. CA1020 and CA1410, respectively; Beijing Solarbio Science \& Technology Co., Ltd.) were used for the detection of apoptosis and ROS levels. For the detection of apoptosis level, cells from all groups were washed twice with $4^{\circ} \mathrm{C}$ sterile PBS and resuspended in $1 \mathrm{ml}$ of $1 \mathrm{X}$ binding buffer to achieve the density of $1 \times 10^{6}$ cells $/ \mathrm{ml}$. Subsequently, $100 \mu \mathrm{l}$ of the suspension $\left(1 \times 10^{5}\right.$ cells) was added to a tube with $5 \mu \mathrm{l}$ Annexin V-FITC at room temperature and agitated gently for $10 \mathrm{~min}$ prior to the addition of $5 \mu \mathrm{l}$ PI for $5 \mathrm{~min}$ at room temperature in light-sensitive environment. PBS (500 $\mu \mathrm{l})$ was added to the tube and mixed evenly, and the mixture was analysed using a flow cytometer. For the detection of ROS levels, dichloro-dihydro-fluorescein diacetate (DCFH-DA) was diluted to $10 \mu \mathrm{mol} / 1$ with DMEM medium without FBS (1:1,000). Medium from each sample was removed and replaced with $1 \mathrm{ml}$ diluted DCFH-DA. Each sample was incubated at room temperature for $20 \mathrm{~min}$ and washed 3 times with medium without FBS to remove excess DCFH-DA outside of the cells. Cells were dissociated with trypsin and detected using a flow cytometer (Gallios; Beckman Coulter, Inc.) with Cell Quest 5.1 software (BD Biosciences).

Western blotting. Western blotting was used for the detection of apoptosis-associated proteins, including Bax, Bcl-2, caspase-3, caspase-12 and cytochrome $\mathrm{C}$ from vaginal epithelial cells obtained from healthy subjects and patients before and after treatment, and for the detection of the expression levels of SOD and eNOS in vitro. Proteins were lysed with RIPA assay lysis buffer (Beyotime Institute of Biotechnology) and a PierceÔ BCA Protein Assay kit (cat. no. 23225; Thermo Fisher Scientific, Inc.) was used to measure the total protein concentration according to manufacturer's instructions. Protein (40 $\mu \mathrm{g} /$ lane) was separated using 10\% SDS-PAGE and transferred onto a PVDF transfer membrane. The membrane was then blocked in 5\% non-fat dry milk for $1 \mathrm{~h}$, followed by overnight incubation at $4{ }^{\circ} \mathrm{C}$ with the following primary antibodies diluted in 5\% BSA: Rabbit anti-Bax (cat. no. ab32124), rabbit anti-Bcl-2 (cat. no. ab32503), rabbit anti-caspase-3 (cat. no. ab13847), rabbit anti-cytochrome-C (cat. no. ab133504), rabbit anti-caspase-12 (cat. no. ab62484), rabbit anti-SOD (cat. no. ab13498) and rabbit anti-eNOS (cat. no. ab76198); all antibodies were purchased from Abcam and all were diluted to $1: 1,000$. Following incubation, the membrane was washed with TBS with $0.1 \%$ Tween-20 (TBST) three times for $10 \mathrm{~min}$ and incubated with horseradish peroxidase-conjugated goat anti-rabbit immunoglobulin G secondary antibody (1:2,000; cat. no. ab6721; Abcam) at room temperature for $2 \mathrm{~h}$. The membrane was washed three times with TBST for $10 \mathrm{~min}$, and the bands were detected using enhanced chemiluminescence (Thermo Fisher Scientific, Inc.). The resulting images were processed using ImageJ 1.46r (National Institutes of Health) for quantitation.

Statistical analysis. SPSS 19.0 software (IBM Corp.) was used for statistical analysis. All data are presented as mean \pm standard deviation. One-way ANOVA with the least significant difference post hoc test was used for multiple comparisons. $\mathrm{P}<0.05$ was considered to indicate a statistically significant difference.

\section{Results}

Berberine improves clinical symptoms of patients with $B V$. Clinical symptoms from all patients before and after berberine treatment were recorded and summarized (Table I). A total of 95\% patients exhibited yellowish leukorrhea at the beginning of the study, which was markedly reduced following berberine treatment. The number of patients with vaginal itching decreased from 88.89 to $36.67 \%$, and the number of patients with local pain decreased from 92.78 to $32.78 \%$ following berberine treatment. Additionally, the number of patients with yellowish leukorrhea decreased from 95 to $10.56 \%$, and the number of patients with foul smell decreased from 36.11 to $5.56 \%$ following berberine treatment. According to the Nugent scores (2), all of the 180 patients were BV-positive (100\%) at the beginning of the study; following berberine treatment, only 13 patients remained positive $(7.22 \%)$, which corresponded to a $92.78 \%$ cure rate. These results indicated that berberine treatment significantly improved clinical symptoms and effectively cured BV.

Berberine treatment reduces oxidative stress in vaginal discharge. SOD and CAT activity, as well as the concentrations of MDA and $\mathrm{H}_{2} \mathrm{O}_{2}$, in the vaginal discharge from control, BT and AT groups were evaluated. SOD and CAT activity levels were significantly lower in the BT group compared with the control group $(\mathrm{P}<0.05$; Fig. $1 \mathrm{~A}$ and $\mathrm{B})$, whereas in the AT group, the activity levels were significantly higher compared with $\mathrm{BT}(\mathrm{P}<0.05$; Fig. 1A and $\mathrm{B})$. By contrast, the levels of MDA and $\mathrm{H}_{2} \mathrm{O}_{2}$ were significantly increased in the BT group compared with the control group $(\mathrm{P}<0.05)$; however, following treatment, these levels decreased significantly compared with the BT group $(\mathrm{P}<0.05)$. These results indicated that oxidative stress in vaginal discharge may be reduced by treatment with berberine.

Berberine protects in $\mathrm{H}_{2} \mathrm{O}_{2}$-treated cells against oxidative damage. The effects of berberine on normal vaginal epithelial cells were investigated. VK2/E6E7 cells were treated with 10, 50 and $100 \mu \mathrm{g} / \mathrm{ml}$ berberine for $24 \mathrm{~h}$, and the MTT assay was used for the evaluation of cell viability. Berberine treatment had no effect on cell viability (Fig. 2A). To specifically evaluate the effects of berberine on oxidative damage, the MTT assay was used in $\mathrm{H}_{2} \mathrm{O}_{2}$-treated cells. The results demonstrated that cell viability was significantly lower in the model group with $\mathrm{H}_{2} \mathrm{O}_{2}$ treatment compared with the control group $(\mathrm{P}<0.05$; Fig. 2B). The berberine treatment groups exhibited a significant increase in cell viability compared with the model group in a dose-dependent manner ( $\mathrm{P}<0.05$; Fig. 2B). Furthermore, based on the flow cytometry results, ROS levels in the model group were significantly higher compared with those in the control group, whereas the berberine-treated groups exhibited significant decreases in ROS levels compared to the model group $(\mathrm{P}<0.05$; Fig. 3). These results demonstrated that berberine may have an antioxidative effect. 
Table I. Clinical symptoms in patients with BV before and after berberine treatment.

\begin{tabular}{|c|c|c|c|c|c|c|c|c|c|c|}
\hline \multirow[b]{2}{*}{ Group } & \multicolumn{2}{|c|}{ Yellowish leukorrhea } & \multicolumn{2}{|c|}{ Foul Smell } & \multicolumn{2}{|c|}{ Pain } & \multicolumn{2}{|c|}{ Itching } & \multicolumn{2}{|c|}{ BV positive } \\
\hline & $\mathrm{N}$ & $\%$ & $\mathrm{~N}$ & $\%$ & $\mathrm{~N}$ & $\%$ & $\mathrm{~N}$ & $\%$ & $\mathrm{~N}$ & $\%$ \\
\hline Before & 171 & 95.00 & 65 & 36.11 & 167 & 92.78 & 160 & 88.89 & 180 & 100 \\
\hline After & 19 & 10.56 & 10 & 5.56 & 59 & 32.78 & 66 & 36.67 & 13 & 7.22 \\
\hline
\end{tabular}

$\mathrm{BV}$, bacterial vaginosis.

A

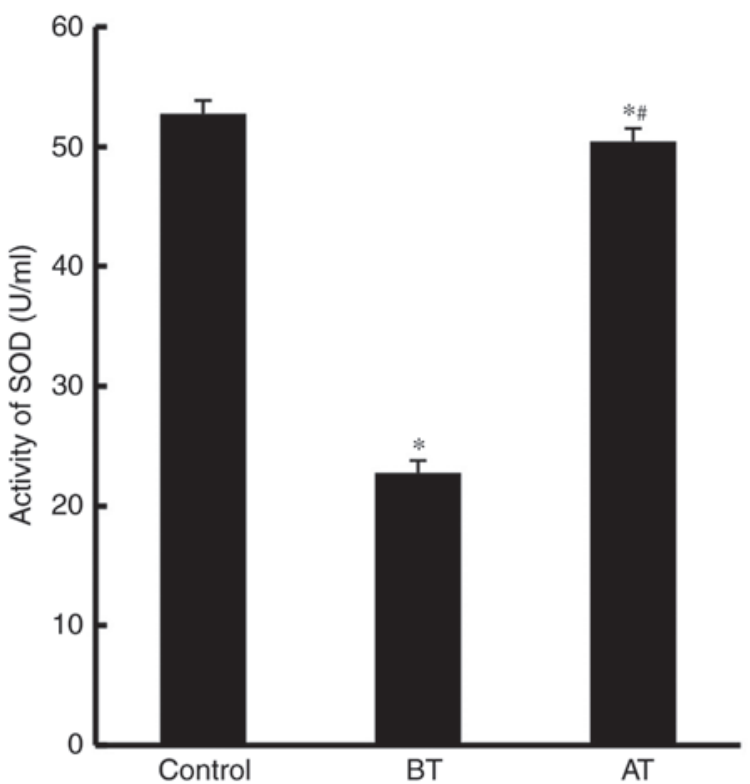

C

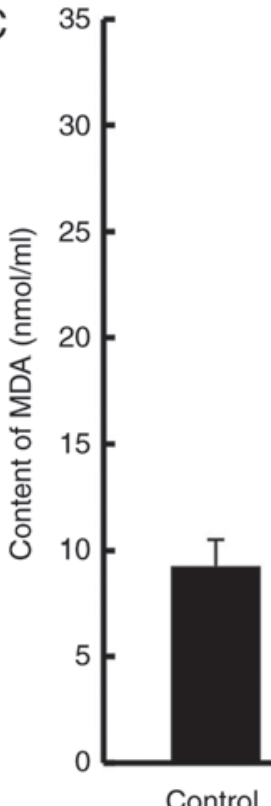

B

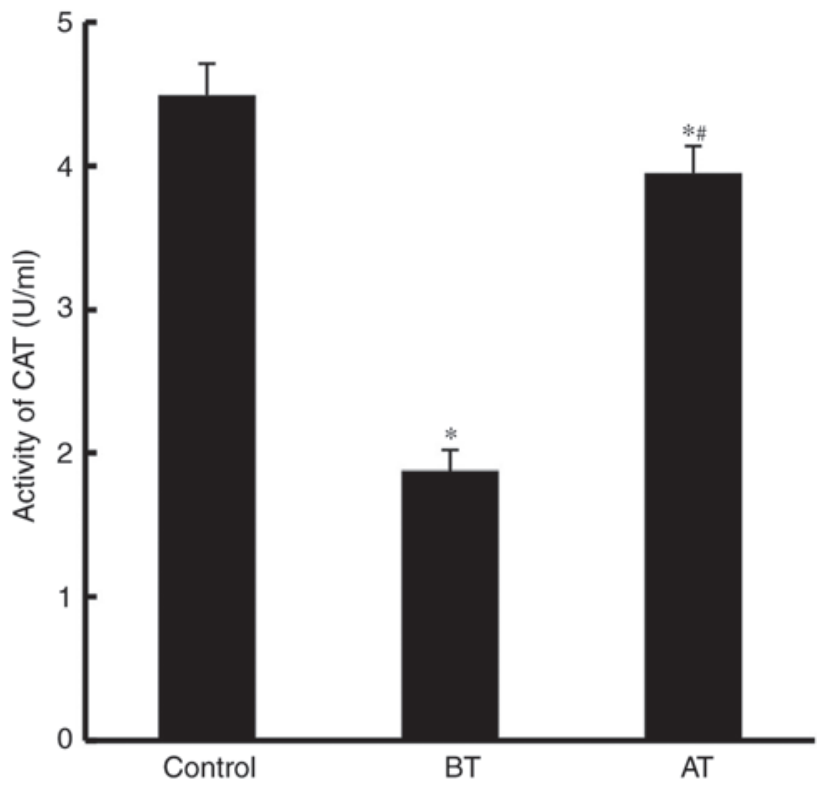

D

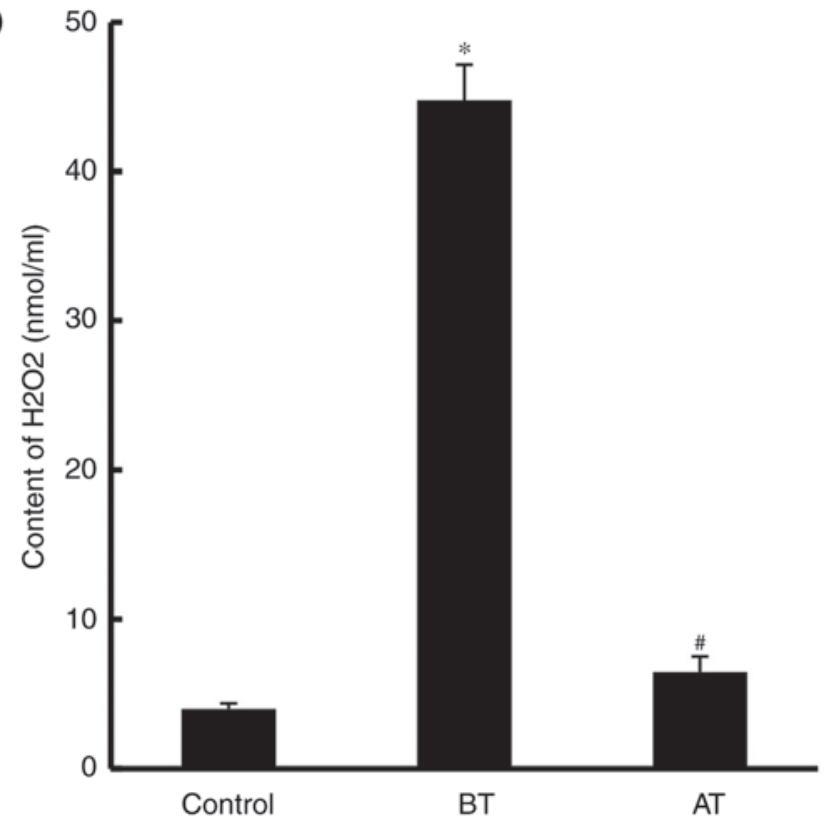

Figure 1. Comparisons between healthy subjects and patients with bacterial vaginosis before and after berberine treatment. Levels of (A) SOD, (B) CAT, (C) MDA and (D) $\mathrm{H}_{2} \mathrm{O}_{2}$ in vaginal discharge. ${ }^{*} \mathrm{P}<0.05$ vs. control; " $\mathrm{P}<0.05$ vs. BT. SOD, superoxide dismutase; CAT, catalase; MDA, malondialdehyde; control, healthy subjects; BT, patients with bacterial vaginosis before berberine treatment; AT, patients with bacterial vaginosis after berberine treatment.

Berberine treatment supresses apoptosis in vaginal epithelial cells. Bcl2, Bax, caspase-3, cytochrome C and caspase-12 are proteins related to cell apoptosis. The expression levels of these proteins in the vaginal epithelial cell samples from 
A

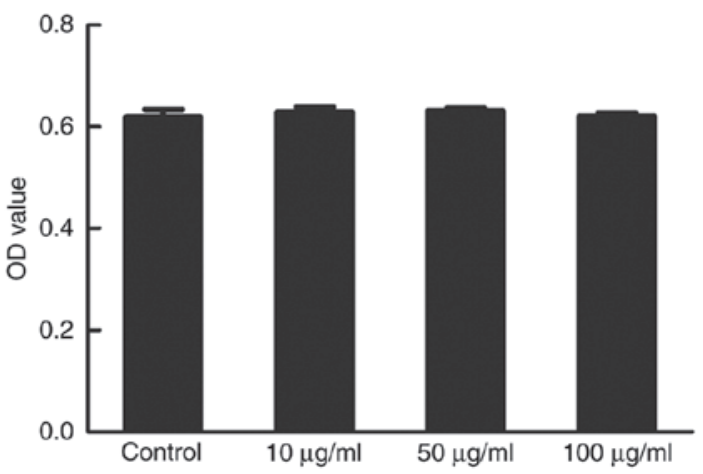

B

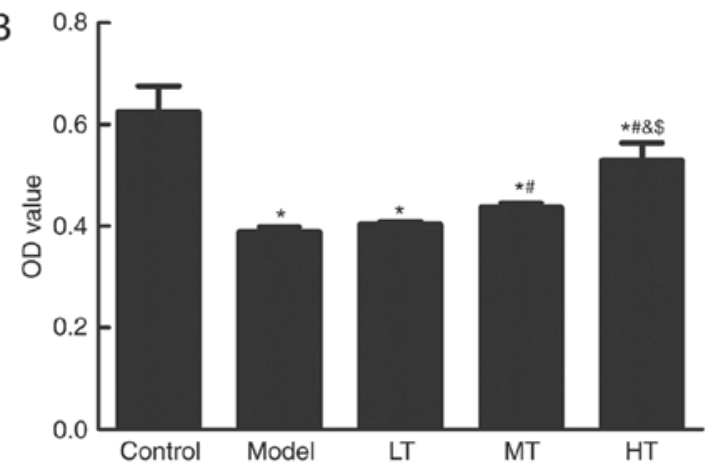

Figure 2. Berberine affects cell viability in an oxidative stress model. (A) Effects of 10,50 and $100 \mu \mathrm{g} / \mathrm{ml}$ berberine on normal vaginal epithelial cells (B) Effects of low-, medium- and high-dose berberine on $\mathrm{H}_{2} \mathrm{O}_{2}$-treated vaginal epithelial cells. " $\mathrm{P}<0.05$ vs. control; " $\mathrm{P}<0.05$ vs. model; ${ }^{\text {\& }} \mathrm{P}<0.05$ vs. LT; ${ }^{\$} \mathrm{P}<0.05$ vs. MT. OD, optical density; model, cells treated with $\mathrm{H}_{2} \mathrm{O}_{2}$; LT, low-dose berberine treatment; MD, medium-dose berberine treatment; HT, high-dose berberine treatment.
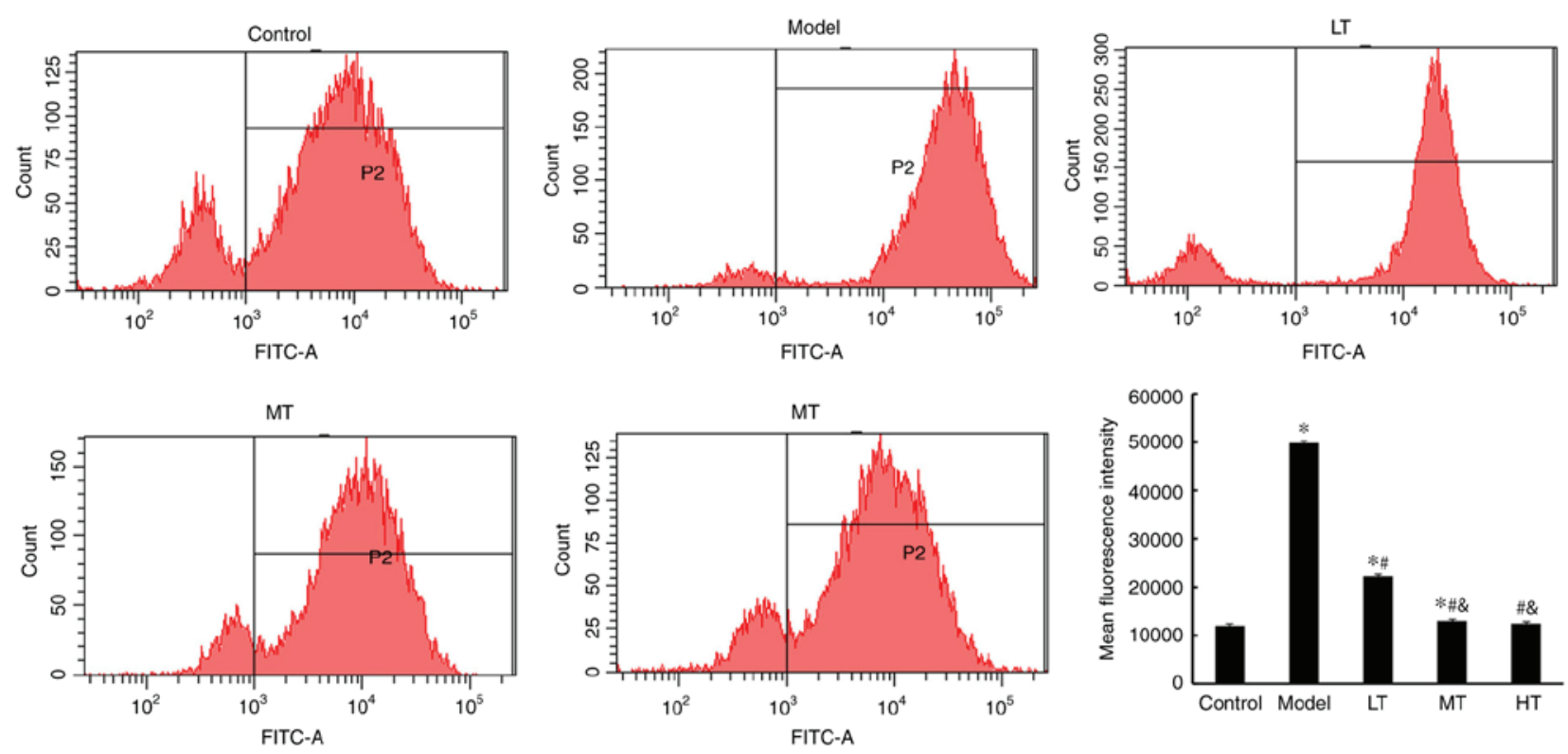

Figure 3. Reactive oxygen species levels detected by fluorescence in an oxidative stress model treated with berberine. " $\mathrm{P}<0.05$ vs. control; " $\mathrm{P}<0.05$ vs. model; ${ }^{\&} \mathrm{P}<0.05$ vs. LT. Model, cells treated with $\mathrm{H}_{2} \mathrm{O}_{2}$; LT, low-dose berberine treatment; MD, medium-dose berberine treatment; MT, high-dose berberine treatment.

patients with BV and healthy subjects are summarized in Fig. 4. The expression levels of Bcl-2 in the BT group were significantly lower compared with those in the control group $(\mathrm{P}<0.05)$, but exhibited a significant increase in the AT group compared with the BT group $(\mathrm{P}<0.05)$. In addition, the BT group exhibited significantly increased levels of Bax, caspase-3, cytochrome $\mathrm{C}$ and caspase-12 expression compared with the control group $(\mathrm{P}<0.05)$, whereas the AT group exhibited reduced levels of these proteins compared with BT $(\mathrm{P}<0.05)$. To further confirm that berberine treatment supressed apoptosis in vaginal epithelial cells, flow cytometry assay was used; the results indicated a higher level of apoptosis in the $\mathrm{H}_{2} \mathrm{O}_{2}$-treated model group compared with the control group ( $\mathrm{P}<0.05$; Fig. 5). Among the berberine-treated groups, apoptosis levels in the MT and HT groups were significantly lower compared with the model group $(\mathrm{P}<0.05$; Fig. 5).

Berberine reduces the levels of oxidative stress and apoptosis markers. Expression levels of SOD and eNOS in the model group were significantly lower compared with those in the control group $(\mathrm{P}<0.05$; Fig. 6). The $\mathrm{Bax} / \mathrm{Bcl} 2$ ratio was significantly higher in the model group compared with that in the control group, which indicated a higher apoptotic rate. The $\mathrm{Bax} / \mathrm{Bcl} 2$ ratio decreased significantly in the berberine-treated groups in a dose-dependent manner $(\mathrm{P}<0.05)$. Similarly, caspase-3, cytochrome $\mathrm{C}$ and caspase- 12 exhibited significant increases in expression levels in the model group compared with the control group $(\mathrm{P}<0.05)$, whereas the berberine-treated groups exhibited decreased levels of expression of these proteins compared with the model group in a dose-dependent manner $(\mathrm{P}<0.05)$.

\section{Discussion}

SOD and CAT are important antioxidative enzymes that are responsible for reducing oxygen species that are chemically active such as $\mathrm{O}_{2}{ }^{-}$, hydroxyl radical and $\mathrm{H}_{2} \mathrm{O}_{2}$. In the present study, patients with $\mathrm{BV}$ exhibited a higher level of oxidative stress in vaginal discharge, based on the supressed levels of 


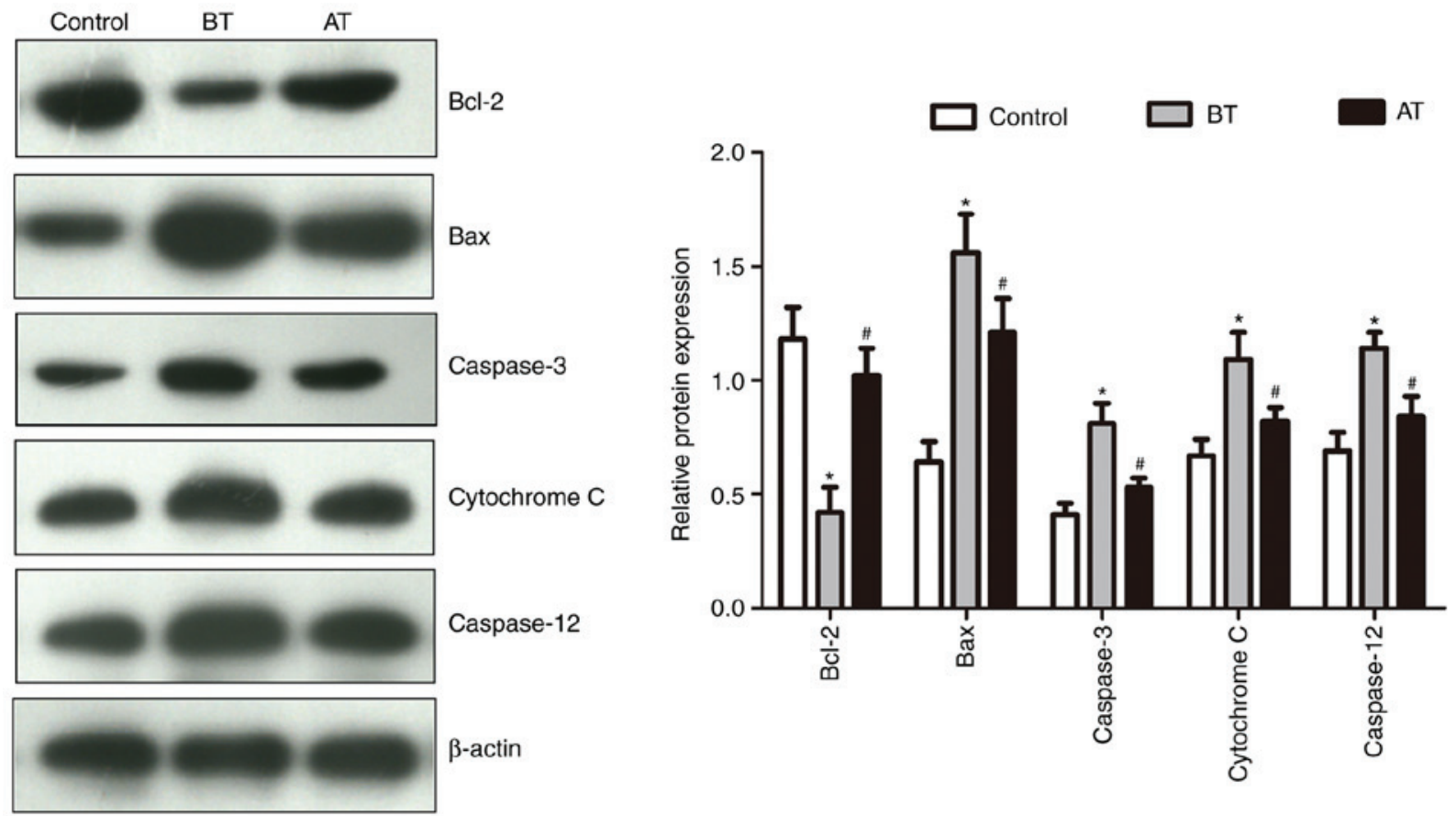

Figure 4. Apoptosis markers in healthy subjects and patients with bacterial vaginosis before and after berberine treatment. The levels of proteins related to apoptosis were determined by western blotting. "P $<0.05$ vs. control, ${ }^{\prime} \mathrm{P}<0.05$ vs. BT. Control, healthy subjects; BT, patients with bacterial vaginosis before berberine treatment; AT, patients with bacterial vaginosis after berberine treatment.
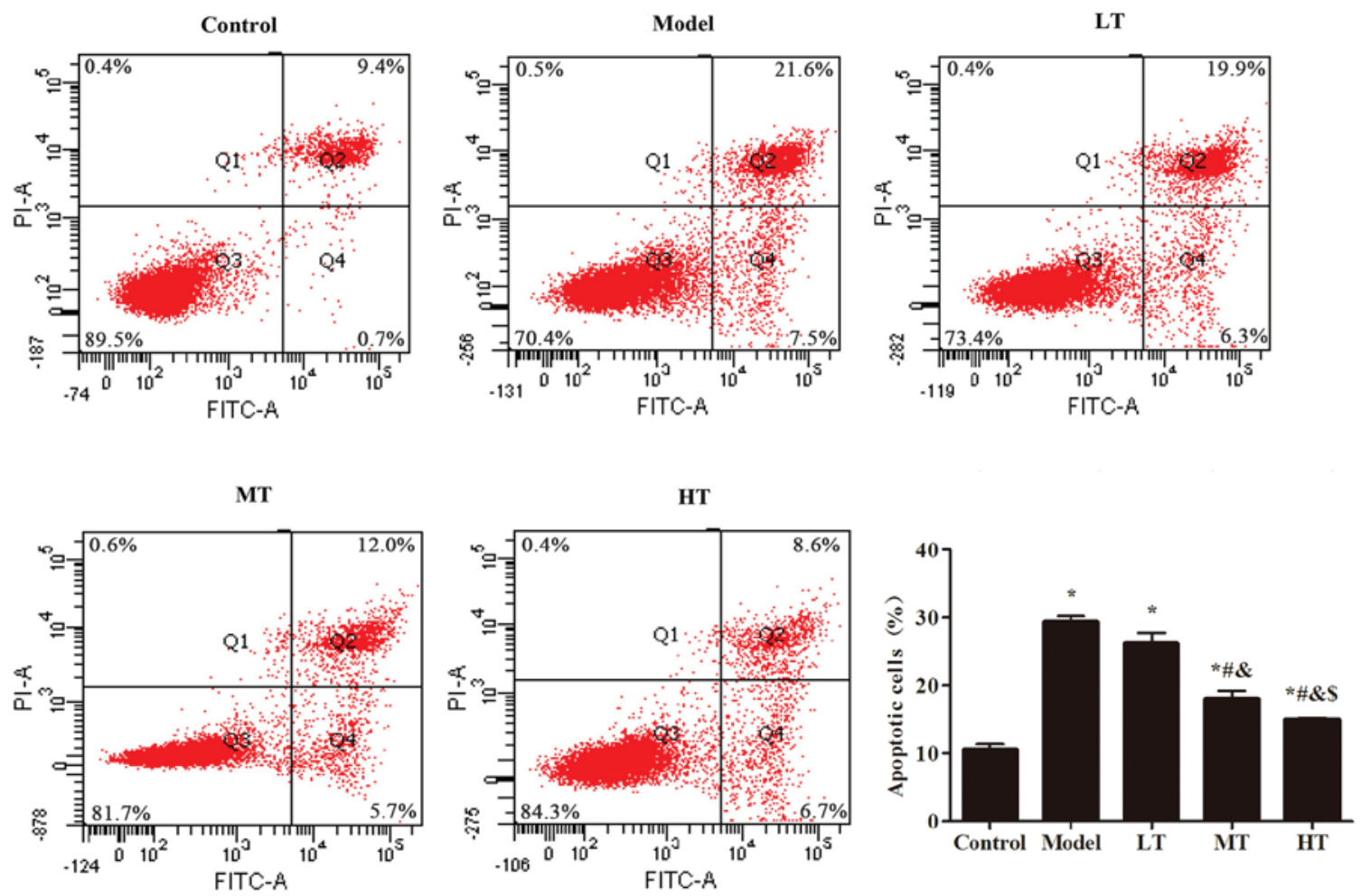

Figure 5. Berberine affects apoptosis in an oxidative stress model. Effects of low-, medium- and high-dose berberine on $\mathrm{H}_{2} \mathrm{O}_{2}$-treated vaginal epithelial cells were determined by flow cytometry. ${ }^{*} \mathrm{P}<0.05$ vs. control, ${ }^{\#} \mathrm{P}<0.05$ vs. model, ${ }^{\&} \mathrm{P}<0.05$ vs. LT group, ${ }^{\mathrm{S}} \mathrm{P}<0.05$ vs. MT. Model, cells treated with $\mathrm{H}_{2} \mathrm{O}_{2} ; \mathrm{LT}$, low-dose berberine treatment; MD, medium-dose berberine treatment; HT, high-dose berberine treatment.

SOD and CAT activities and the significantly higher levels of $\mathrm{H}_{2} \mathrm{O}_{2}$ and MDA compared with healthy subjects. Following berberine treatment, activity levels of SOD and CAT were significantly increased, which resulted in a reduction of the level of $\mathrm{H}_{2} \mathrm{O}_{2}$ and possibly other ROS. Reduced levels of ROS also lead to less lipid peroxidation as exhibited by reduced 


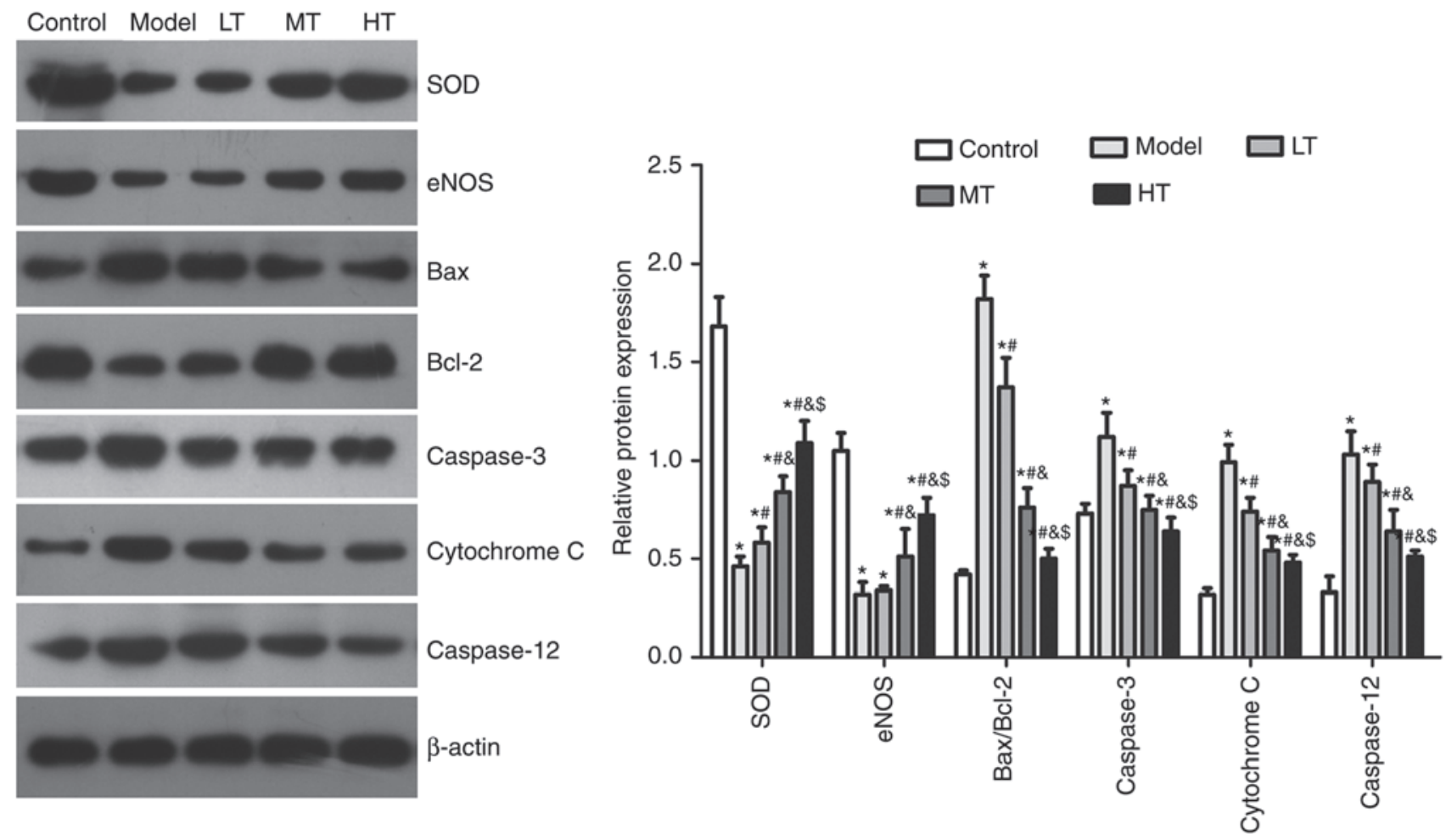

Figure 6. Berberine affects oxidative stress and apoptosis marker expression in an oxidative stress model. Effects of low-, medium- and high-dose berberine on apoptosis marker expression in $\mathrm{H}_{2} \mathrm{O}_{2}$-treated vaginal epithelial cells were determined western blotting. ${ }^{.} \mathrm{P}<0.05$ vs. control, ${ }^{\prime \prime} \mathrm{P}<0.05$ vs. model, ${ }^{\text {\&P}}<0.05$ vs. LT, ${ }^{\$} \mathrm{P}<0.05$ vs. MT. Model, cells treated with $\mathrm{H}_{2} \mathrm{O}_{2} ; \mathrm{LT}$, low-dose berberine treatment; MD, medium-dose berberine treatment; HT, high-dose berberine treatment; SOD, superoxide dismutase; eNOS, endothelial nitric oxide synthase.

MDA level following treatment. Taken together, these findings suggest that berberine may be effective in reducing oxidative stress in vaginal discharge from patients with BV. This is similar to the results from a previous study on other diseases such as diabetes mellitus, in which antioxidative effects of berberine were also described (15).

The Bcl-2 family of intracellular proteins regulates programmed cell death by activating the caspase family (34). Bax and Bcl-2 are integral membrane proteins on the mitochondrial membrane (30). Bcl-2 is an inhibitor of apoptosis, whereas Bax promotes cell death (30). The Bax/Bcl2 ratio was significantly higher in vaginal epithelial cells in patients prior to treatment when compared with that in healthy subjects, indicating a higher level of apoptosis. A previous study has suggested that $\mathrm{Bcl}-2$ is responsible for maintaining the integrity of the mitochondrial membrane, whereas Bax contributes to the formation of channels for the release of cytochrome $\mathrm{C}$ from within the mitochondria, which activates the caspase cascade for cell death (34). In the present study, berberine treatment was able to lower the $\mathrm{Bax} / \mathrm{Bcl} 2$ ratio significantly, which in turn lowered the levels of the apoptosis-associated proteins caspase- 3 , caspase- 12 and cytochrome C.

Results from the in vitro experiment in the present study using human vaginal epithelial cells further supported the antiapoptotic effects of berberine. Similar to the in vivo study, berberine-treated cells exhibited a significantly lower $\mathrm{Bax} / \mathrm{Bcl} 2$ ratio, which reduced the release of cytochrome $\mathrm{C}$ from the mitochondria and the activation of the caspase family. In addition, the levels of SOD and eNOS were significantly higher in the treated groups compared with the model group, suggesting less oxidative stress and better protection against oxidative damage for cells. The treatment groups exhibited lower levels of ROS and apoptosis and increased cell viability compared with the model group. These differences increased with higher doses of berberine. These results further supported the antioxidative and antiapoptotic effects of berberine.

Marked improvements were observed in all documented clinical symptoms of 180 patients with BV following berberine treatment. These improvements included lower incidence of yellowish leukorrhea, vaginal itching, vaginal pain, coloration and smell compared with that prior to the treatment. Therefore, by reducing the level of oxidative stress and programmed cell death, berberine treatment may be effective in improving the clinical symptoms of patients with BV. The $92.82 \%$ BV cure rate based on the Nugent score suggested a higher efficacy of berberine treatment compared with the current standard antibiotic treatments (75-86\%) (6). Although berberine treatment raises no concerns about antibiotic resistance, further clinical studies are needed to examine BV recurrence following treatment and to determine the optimal dosage for possible shorter treatment periods. In addition, further in vitro studies are required to investigate the detailed mechanisms of the effects of berberine, such as its effects on gene expression, and to provide insight for possible treatment options for other types of vaginitis.

\section{Acknowledgements}

Not applicable. 


\section{Funding}

The present study was supported by the Traditional Chinese Medicine Science and Technology Development Plan Project of Shandong Province (grant no. 2017-368).

\section{Availability of data and materials}

The datasets used and analyzed during the present study are available from the corresponding author upon reasonable request.

\section{Authors' contributions}

WW designed the experiments. XM and JD performed the experiments, analyzed all data and were major contributors in writing the manuscript. XC and QC performed a part of the experiments. All authors read and approved the final manuscript.

\section{Ethics approval and consent to participate}

Ethical approval was obtained from the Ethics Committee of Yantai Hospital of Traditional Chinese Medicine. All procedures performed in studies involving human participants were in accordance with the ethical standards of Yantai Hospital of Traditional Chinese Medicine and with the 1964 Declaration of Helsinki and its later amendments or comparable ethical standards. Written informed consent was obtained from all participants.

\section{Patient consent for publication}

Not applicable.

\section{Competing interests}

The authors declare that they have no competing interests.

\section{References}

1. Nyirjesy P: Management of persistent vaginitis. Obstet Gynecol 124 1135-1146, 2014.

2. Atashili J, Poole C, Ndumbe PM, Adimora AA and Smith JS: Bacterial vaginosis and HIV acquisition: A meta-analysis of published studies. AIDS 22: 1493-1501, 2008.

3. Brocklehurst P, Gordon A, Heatley E and Milan SJ: Antibiotics for treating bacterial vaginosis in pregnancy. Cochrane Database Syst Rev CD000262, 2013.

4. Peters BM, Yano J, Noverr MC and Fidel PL Jr: Candida vaginitis: When opportunism knocks, the host responds. PLoS Pathog 10: e1003965, 2014.

5. Donders GG, Zodzika J and Rezeberga D: Treatment of bacterial vaginosis: What we have and what we miss. Expert Opin Pharmacother 15: 645-657, 2014.

6. Voorspoels J, Casteels M, Remon JP and Temmerman M: Local treatment of bacterial vaginosis with a bioadhesive metronidazole tablet. Eur J Obstet Gynecol Reprod Biol 105: 64-66, 2002.

7. Paavonen J, Mangioni C, Martin MA and Wajszczuk CP: Vaginal clindamycin and oral metronidazole for bacterial vaginosis: A randomized trial. Obstet Gynecol 96: 256-260, 2000.

8. Livengood CH 3rd, Ferris DG, Wiesenfeld HC, Hillier SL, Soper DE, Nyirjesy P, Marrazzo J, Chatwani A, Fine P, Sobel J, et al: Effectiveness of two tinidazole regimens in treatment of bacterial vaginosis: A randomized controlled trial. Obstet Gynecol 110: 302-309, 2007.
9. Brandt M, Abels C, May T, Lohmann K, Schmidts-Winkler I and Hoyme UB: Intravaginally applied metronidazole is as effective as orally applied in the treatment of bacterial vaginosis, but exhibits significantly less side effects. Eur J Obstet Gynecol Reprod Biol 141: 158-162, 2008.

10. Hanson JM, McGregor JA, Hillier SL, Eschenbach DA, Kreutner AK, Galask RP and Martens M: Metronidazole for bacterial vaginosis. A comparison of vaginal gel vs. oral therapy. J Reprod Med 45: 889-896, 2000.

11. Nagaraja P: Antibiotic resistance of Gardnerella vaginalis in recurrent bacterial vaginosis. Indian J Med Microbiol 26: 155-157, 2008.

12. Bahar H, Torun MM, Oçer F and Kocazeybek B: Mobiluncus species in gynaecological and obstetric infections: Antimicrobial resistance and prevalence in a Turkish population. Int $\mathrm{J}$ Antimicrob Agents 25: 268-271, 2005.

13. Beigi RH, Austin MN, Meyn LA, Krohn MA and Hillier SL: Antimicrobial resistance associated with the treatment of bacterial vaginosis. Am J Obstet Gynecol 191: 1124-1129, 2004.

14. Abd El-Wahab AE, Ghareeb DA, Sarhan EE, Abu-Serie MM and El Demellawy MA: In vitro biological assessment of Berberis vulgaris and its active constituent, berberine: Antioxidants, anti-acetylcholinesterase, anti-diabetic and anticancer effects. BMC Complement Altern Med 13: 218, 2013.

15. Li Z, Geng YN, Jiang JD and Kong WJ: Antioxidant and anti-inflammatory activities of berberine in the treatment of diabetes mellitus. Evid Based Complement Alternat Med 2014: 289264, 2014.

16. Dong H, Zhao Y, Zhao L and Lu F: The effects of berberine on blood lipids: A systemic review and meta-analysis of randomized controlled trials. Planta Med 79: 437-446, 2013.

17. Domitrović R, Cvijanović O, Pernjak-Pugel E, Skoda M, Mikelić L and Crnčević-Orlić Z: Berberine exerts nephroprotective effect against cisplatin-induced kidney damage through inhibition of oxidative/nitrosative stress, inflammation, autophagy and apoptosis. Food Chem Toxicol 62: 397-406, 2013.

18. Yao J, Kong W and Jiang J: Learning from berberine: Treating chronic diseases through multiple targets. Sci China Life Sci 58: 854-859, 2015.

19. Xu J, Duan X, Yang J, Beeching JR and Zhang P: Enhanced reactive oxygen species scavenging by overproduction of superoxide dismutase and catalase delays postharvest physiological deterioration of cassava storage roots. Plant Physiol 161: 1517-1528, 2013.

20. Iwase T, Tajima A, Sugimoto S, Okuda K, Hironaka I, Kamata Y, Takada K and Mizunoe Y: A simple assay for measuring catalase activity: A visual approach. Sci Rep 3: 3081, 2013.

21. King AL, Polhemus DJ, Bhushan S, Otsuka H, Kondo K, Nicholson CK, Bradley JM, Islam KN, Calvert JW, Tao YX, et al: Hydrogen sulfide cytoprotective signaling is endothelial nitric oxide synthase-nitric oxide dependent. Proc Natl Acad Sci USA 111: 3182-3187, 2014.

22. Rochette L, Lorin J, Zeller M, Guilland JC, Lorgis L, Cottin Y and Vergely C: Nitric oxide synthase inhibition and oxidative stress in cardiovascular diseases: Possible therapeutic targets? Pharmacol Ther 140: 239-257, 2013.

23. Mao K, Chen S, Chen M, Ma Y, Wang Y, Huang B, He Z, Zeng Y, $\mathrm{Hu} \mathrm{Y}$, Sun S, et al: Nitric oxide suppresses NLRP3 inflammasome activation and protects against LPS-induced septic shock. Cell Res 23: 201-212, 2013.

24. Cortese-Krott MM and Kelm M: Endothelial nitric oxide synthase in red blood cells: Key to a new erythrocrine function? Redox Biol 2: 251-258, 2014.

25. Gill SS, Hasanuzzaman M, Nahar K, Macovei A and Tuteja N: Importance of nitric oxide in cadmium stress tolerance in crop plants. Plant Physiol Biochem 63: 254-261, 2013.

26. Ayala A, Muñoz MF and Argüelles S: Lipid peroxidation: Production, metabolism, and signaling mechanisms of malondialdehyde and 4-hydroxy-2-nonenal. Oxid Med Cell Longev 2014: 360438, 2014.

27. Ahmad A, Singhal U, Hossain MM, Islam N and Rizvi I: The role of the endogenous antioxidant enzymes and malondialdehyde in essential hypertension. J Clin Diagn Res 7: 987-990, 2013.

28. Kwiecien S, Jasnos K, Magierowski M, Sliwowski Z, Pajdo R, Brzozowski B, Mach T, Wojcik D and Brzozowski T: Lipid peroxidation, reactive oxygen species and antioxidative factors in the pathogenesis of gastric mucosal lesions and mechanism of protection against oxidative stress-induced gastric injury. J Physiol Pharmacol 65: 613-622, 2014. 
29. Brentnall M, Rodriguez-Menocal L, De Guevara RL, Cepero E and Boise LH: Caspase-9, caspase-3 and caspase-7 have distinct roles during intrinsic apoptosis. BMC Cell Biol 14: 32, 2013.

30. Jia G, Wang Q, Wang R, Deng D, Xue L, Shao N, Zhang Y, $\mathrm{Xia} X$, Zhi F and Yang Y: Tubeimoside-1 induces glioma apoptosis through regulation of $\mathrm{Bax} / \mathrm{Bcl}-2$ and the ROS/Cytochrome C/Caspase-3 pathway. Onco Targets Ther 8: 303-311, 2015.

31. Hoshyar R, Bathaie SZ and Sadeghizadeh M: Crocin triggers the apoptosis through increasing the $\mathrm{Bax} / \mathrm{Bcl}-2$ ratio and caspase activation in human gastric adenocarcinoma, AGS, cells. DNA Cell Biol 32: 50-57, 2013

32. Kim ME, Ha TK, Yoon JH and Lee JS: Myricetin induces cell death of human colon cancer cells via BAX/BCL2-dependent pathway. Anticancer Res 34: 701-706, 2014.
33. Shirali S, Aghaei M, Shabani M, Fathi M, Sohrabi M and Moeinifard M: Adenosine induces cell cycle arrest and apoptosis via cyclinD1/Cdk4 and Bcl-2/Bax pathways in human ovarian cancer cell line OVCAR-3. Tumour Biol 34: 1085-1095, 2013.

34. Cory S and Adams JM: The Bcl2 family: Regulators of the cellular life-or-death switch. Nat Rev Cancer 2: 647-656, 2002.

(c) (7) $\fallingdotseq$ This work is licensed under a Creative Commons Attribution-NonCommercial-NoDerivatives 4.0 International (CC BY-NC-ND 4.0) License. 